\title{
PEMODELAN ARSITEKTUR ENTERPRISE SISTEM INFORMASI AKADEMIK PADA PERGURUAN TINGGI MENGGUNAKAN ENTERPRISE ARCHITECTURE PLANNING
}

\author{
Andy Prasetyo Utomo \\ Dosen Fakultas Teknik, Program Studi Sistem Informasi \\ Universitas Muria Kudus \\ Email: andyutomo@gmail.com
}

\begin{abstract}
ABSTRAK
Perguruan tinggi adalah sebuah enterprise yang bergerak di bidang pendidikan. Pada era sekarang ini untuk mendukung aktifitas utama di perguruan tinggi sangat dibutuhkan adanya dukungan sistem informasi. Kegagalan dalam penerapan sistem informasi dalam sebuah perguruan tinggi seringkali disebabkan karena tidak ada perencanaan yang matang. Perencanaan sistem informasi dalam sebuah perguruan tinggi bisa diwujudkan dalam bentuk blueprint. Enterprise Architecture Planning (EAP) adalah suatu proses pendefinisian arsitektur untuk penggunaan informasi dalam rangka mendukung bisnis dan perencanaan untuk mengimplementasikan arsitektur tersebut. EAP dapat digunakan untuk membuat sebuah blueprint teknologi pada sebuah enterprise. Pada jurnal ini akan membahas penggunaan konsep EAP untuk membuat blueprint sistem informasi akademik di perguruan tinggi yang berisikan berbagai arsitektur diantaranya arsitektur data, aplikasi dan teknologi.
\end{abstract}

Kata kunci: EAP, enterprise, blueprint, Perguruan Tinggi.

\section{ABSTRACT}

The college is an enterprise engaged in the field of education. In this era to support the main activities in college desperately needed the support of information systems. Failures in the application of information systems in a college is often caused because there is no proper planning. Planning information system in a university can be realized in the form of blueprints. Enterprise Architecture Planning (EAP) is a process of defining architectures for the use of information in order to support the business and plans to implement the architecture. EAP can be used to create a blueprint technology on an enterprise. In this paper will discuss the use of the concept of EAP to make a blueprint of academic information system at the university that contains a variety of architectures including data architecture, applications and technologies

Keywords: EAP, enterprise, blueprint, college.

\section{PENDAHULUAN}

Perubahan lingkungan dan kebutuhan dari bisnis berubah secara cepat yang memaksa manajemen eksekutif untuk memiliki informasi yang up to date setiap waktunya, sehingga mereka bisa mengelola bisnisnya dengan lebih efektif. Perusahaan harus bisa membuat ketersediaan informasi dalam tingkat organisasi, bukan hanya dalam tingkat unit bisnis. Pengoptimalan informasi dalam tingkat organisasi mensyaratkan integrasi kesemua informasi yang dimiliki oleh unit-unit bisnis.

Enterprise adalah sekumpulan organisasi yang memiliki beberapa tujuan/prinsip umum dan atau suatu garisan dasar [1]. Perguruan Tinggi merupakan sebuah enterprise yang bergerak di bidang pendidikan. Perguruan tinggi pada umunya memiliki beberapa unit bisnis seperti: bagian umum, keuangan, kepegawaian, perencanaan dan sistem informasi, penerbitan dan publikasi, serta kegiatan utama penerimaan mahasiswa, operasional akademik dan wisuda. Masing-masing unit bisnis memiliki sistem yang dikembangkan sendiri, sehingga sering terjadi bentrok dalam pengalokasian sumber daya, data yang digunakan tidak konsisten, karena tidak diolah secara real time. Pengelolaan sistem berorientasikan data, bukan berorientasi pengguna.

Kegagalan dalam penerapan sistem informasi dalam sebuah perguruan tinggi seringkali disebabkan karena tidak ada perencanaan yang matang yang meliputi organisasi secara komprehensif. Penerapan hanya dilakukan berdasarkan kebutuhan sesaat saja tanpa adanya perencanaan menyeluruh dan hanya untuk satu fungsi tertentu saja dari organisasi. Sehingga diperlukan suatu bentuk blueprint mengenai informasi organisasi berupa arsitektur enterprise, sehingga dapat digunakan untuk mendukung strategi-strategi kebijakan yang akan diambil pihak manajemen dalam melakukan langkah pengembangan sistem yang terorganisasi dan terintegrasi. 
Pada jurnal ini akan mencoba menerapkan konsep Enterprise Architecture Planning (EAP) dalam membuat blueprint perencanaan sistem informasi akademik pada perguruan tinggi.

\section{METODOLOGI PENELITIAN}

Enterprise Architecture adalah pengorganisasian secara logic untuk proses bisnis utama dan kemampuan Teknologi Informasi (TI) yang mencerminkan kebutuhan integrasi dan standarisasi model operasi perusahaan berdasarkan Center for Information Systems Research [2]. Enterprise Architecture adalah sekumpulan prinsipprinsip, metode, dan model yang digunakan dalam perancangan dan realisasi dari sebuah struktur organisasi perusahaan, proses bisnis, sistem informasi dan infrastruktur [1]. Berdasarkan deskripsi diatas maka dapat disimpulkan enterprise architecture adalah prinsip-prinsip, metode, dan model yang digunakan dalam perancangan dan realisasi dari sebuah struktur organisasi perusahaan, proses bisnis, sistem informasi dan infrastruktur. Enterprise Architecture Planning adalah suatu proses pendefinisian arsitektur untuk penggunaan informasi dalam rangka mendukung bisnis dan perencanaan untuk mengimplementasikan arsitektur tersebut [3].

Metodologi dan model Enterprise Architecture Planning adalah bagian awal dari bagian utama pengetahuan Enterprise Architecture yang masih relevan dan telah banyak mempengaruhi framework, metodologi dan praktek praktek terbaik di sektor publik dan privat [4]. Dalam jurnal ini metodologi penelitian yang digunakan akan disesuaikan dengan langkah - langkah pemodelan arsitektur yang ada di dalam EAP, yaitu :

a. Inisiasi perencanaan

b. Pemodelan bisnis

c. Arsitektur sistem dan teknologi saat ini

d. Pembangunan model arsitektur enterprise

1) Arsitektur data

2) Arsitektur aplikasi

3) Arsitektur teknologi

4) Implementasi

\section{HASIL PENELITIAN DAN PEMBAHASAN}

Langkah - langkah pemodelan yang ada di dalam EAP merupakan tahapan yang bisa dilakukan dalam membangun sebuah blueprint untuk suatu arsitektur. Dengan mengikuti langkah - langkah yang ada di dalam konsep EAP tersebut akan digunakan untuk memodelkan sistem informasi akademik di perguruan tinggi secara umum. Hasil dari setiap langkah tersebut adalah sebagai berikut.

\subsection{Inisiasi Perencanaan}

Tahap awal dari EAP adalah inisialisasi perencanaan, yakni mendefinisikan organisasi sebagai objek dengan menjabarkan visi dan misi organisasi yang dihubungkan dengan visi dari perencanaan sistem informasi sehingga pengembangan arsitektur dapat dilakukan sesuai dengan tujuan bisnis.

Sesuai dengan kebereadaanya sebagai sebuah perguruan tinggi, core business dari perguruan tinggi terdiri atas 3 komponen utama yakni: pendidikan dan pengajaran, pengabdian kepada masyarakat, dan penelitian yang disebut dengan tri dharma perguruan tinggi. Dengan menyelenggarakan jasa pendidikan kepada masyarakat untuk menghasilkan lulusan yang akan diterjunkan kembali ke masyarakat.

Penentuan visi dan misi ke dapan sangat diperlukan sebagai pedoman untuk menentukan berbagai strategi TI yang diperlukan untuk mendukung visi dan misi tersebut. Pemilihan pendekatan metodologi perencanaan akan menentukan hasil dari blueprint yang akan dibuat.

\subsection{Pemodelan Bisnis}

Struktur organisasi di dalam perguruan tinggi menjadi dasar utama dalam melakukan pemodelan bisnis. Struktur organisasi akan menunjukkan bagian apa saja yang akan ditangani oleh sebuah perguruan tinggi. Sehingga penentuan struktur organisasi akan sangat menentukan dalam langkah pemodelan bisnis.

Sebagai sebuah lembaga pendidikan perguruan tinggi menjalankan Tri Dharma perguruan tinggi yakni pendidikan, penelitian dan pengabdian kepada masyarakat. Sehingga aktivitas utama perguruan tinggi dikelompokkan ke dalam bidang Pendidikan, Penelitian dan Pengabdian Masyarakat. Dalam tulisan ini hanya akan dibahas bidang pendidikan (akademik) dan penelitian, tidak termasuk pengabdian masyarakat.

Berdasarkan konsep rantai nilai [2], area fungsional utama untuk model pendidikan di perguruan tinggi secara umum dapat dikelompokkan ke dalam kegiatan utama dan kegiatan pendukung. Kegiatan utama terdiri dari 
penerimaan mahasiswa, operasional akademik dan wisuda. Sedangkan kegiatan pendukung terdiri dari kegiatan yang berhubungan dengan manajemen sumber daya (umum), manajemen keuangan, perencanaan dan sistem informasi, dan penerbitan dan publikasi. Gambar 1, memperlihatkan rantai nilai untuk model pendidikan dan penelitian sebuah perguruan tinggi.

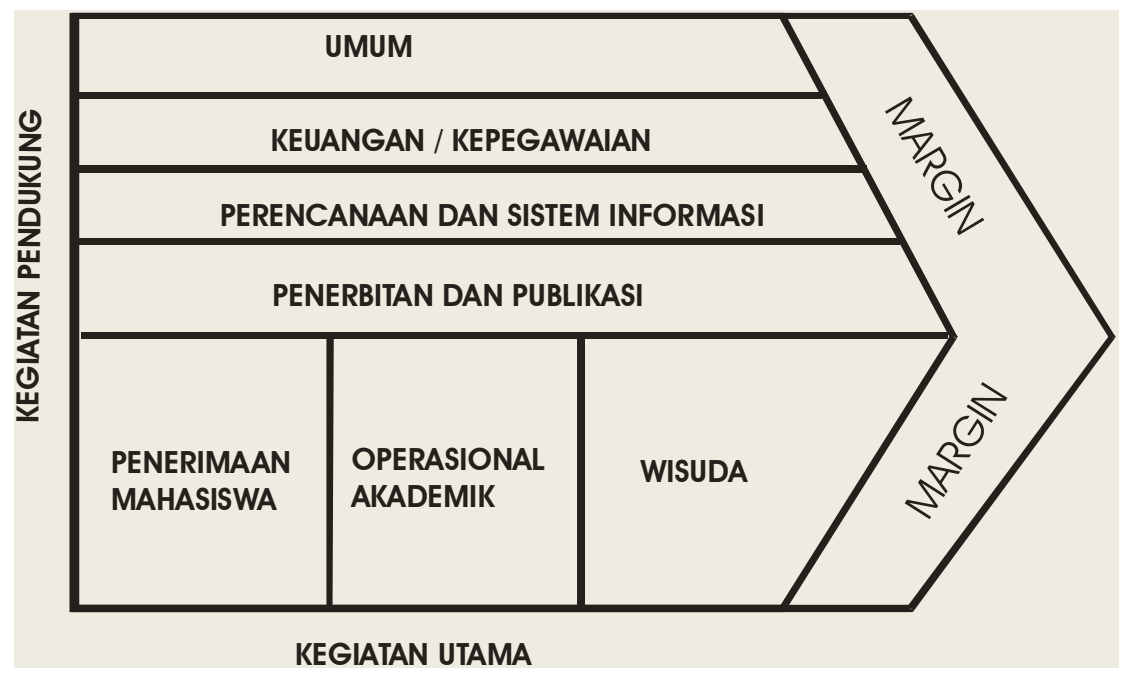

Gambar 1. Rantai nilai perguruan tinggi

Masing-masing kegiatan utama dapat diuraikan sebagai berikut:

1. Penerimaan mahasiswa adalah semua kegiatan dimulai dari proses penerimaan mahasiswa baru, seleksi administrasi mahasiswa baru.

2. Operasional akademik adalah semua kegiatan yang berkaitan dengan usaha untuk kegiatan belajar mengajar selama masa akademik mahasiswa.

3. Wisuda adalah kegiatan melepas mahasiswa mahasiswa secara akademik sebagai akhir dari studi mahasiswa.

Masing-masing kegiatan pendukung dapat dijabarkan sebagai berikut :

1. Bagian umum adalah bagian bertanggung jawab atas kelancaran kegiatan penyelenggaraan fasilitas pendidikan, telah melaksanakan pengembangan-pengembangan sarana-prasarana dari tahun ketahun, baik sarana fisik maupun sarana penunjang kegiatan penyelenggaraan pendidikan.

2. Keuangan dan kepegawaian adalah aktifitas yang berkaitan dengan manajemen keuangan penetapan budget investasi serta penentuan kebutuhan, pemantauan dan alokasi sumber daya manusia.

3. Perencanaan dan Sistem Informasi adalah kegiatan yang berkaitan dengan pengelolaan dan pengembangan peralatan dan jaringan sistem informasi.

4. Penerbitan dan publikasi adalah kegiatan yang berkaitan dengan pengelolaan dan penerbitan jurnal, buletin dan buku ajar mahasiswa.

Setelah melakukan inisiasi terhadap area fungsi bisnis organisasi dengan pemanfaatan rantai nilai potter, maka dapat dilakukan penyusunan struktur dekomposisi dari fungsi bisnis dengan menggunakan bagan hirarki fungsi.

Sesuai dengan ruang lingkup dan batasan pada jurnal ini maka fungsi yang didekomposisikan adalah yang berkaitan dengan akademik sebagai fungsi utama dengan penjabaran pada Penerimaan mahasiswa, Operasional Akademik, Pelaksanaan Wisuda, Bagian Umum, Manajemen Keuangan dan kepegawaian, Perencanaan dan sistem informasi, serta penerbitan dan publikasi. Hal itu dapat digambarkan sebagai berikut

1. Penerimaan mahasiswa

a. Perencanaan penerimaan mahasiswa

i. Pemilihan panitia penerimaan mahasiswa

ii. Penentuan anggaran

iii. Penentuan standarisasi penerimaan

iv. Penjadwalan kegiatan penerimaan mahasiswa

b. Pelaksanaan Seleksi c. Penyelenggaraan Seleksi

i. Penyusunan materi ujian masuk

ii. Penerimaan pendaftaran

iii. Pelaksanaan ujian masuk

d. Pendaftaran ulang mahasiswa baru

2. Operasional Akademik

a. Perencanaan pelaksanaan kegiatan akademik 
i. Pengembangan kurikulum

ii. Penetapan kalender akademik

b. Pendaftaran Ulang

i. Heregistrasi Akademik

ii. Pemberian matakuliah yang ditawarkan

iii. Pelaksanaan pembimbingan akademik

iv. Pemrosesan dan pencetakan Kartu Rencana Studi

v. Perubahan Rencana Studi

c. Proses kuliah

i. Penetapan dosen pengampu matakuliah

ii. Penyusunan jadwal

iii. Rekap pelaksanaan kuliah

d. Proses evaluasi

i. Pelaksanaan ujian

ii. Pemberian nilai

e. Pelaksanaan cuti akademik mahasiswa

f. Ujian akhir mahasiswa

3. Pelaksanaan Wisuda

a. Penetapan syarat kelulusan

b. Pembuatan ijazah

c. Pembuatan transkrip nilai

4. Bagian Umum

a. Pelaksanaan pengadaan sarana dan prasarana

b. Pelaksanaan manajemen inventaris

c. Pengawasan dan evaluasi pemanfaatan sarana dan prasarana

d. Pelaporan inventaris kantor e. Pelaporan manajemen pengadaan

5. Manajemen Keuangan dan kepegawaian

a. Penetapan anggaran

b. Pengalokasian anggaran

c. Pemantauan dan evaluasi

d. Revisi anggaran

e. Sistem akuntansi keuangan

f. Perencanaan pengembangan pegawai

i. Penetapan kebijakan manajemen rekruitmen

ii. Penetapan kebijakan administrasi pegawai iii. Penetapan belanja pegawai

g. Perhitungan pembayaran

i. Perhitungan gaji

ii. Perhitungan honor

iii. Perhitungan transportasi

h. Evaluasi prestasi pegawai

6. Perencanaan dan sistem informasi

a. Pelaksanaan administrasi laboratorium

b. Pelaporan administrasi laboratorium

c. Pengembangan software atau sistem informasi

7. Penerbitan dan Publikasi

a. Pelaksanaan administrasi jurnal

b. Pelaksanaan administrasi buletin

c. Pelaksanaan administrasi buku ajar

Gambar 2. berikut ini menunjukkan keterhubungan antara stakeholder dengan fungsi bisnis utama dan pendukung di sebuah perguruan tinggi.

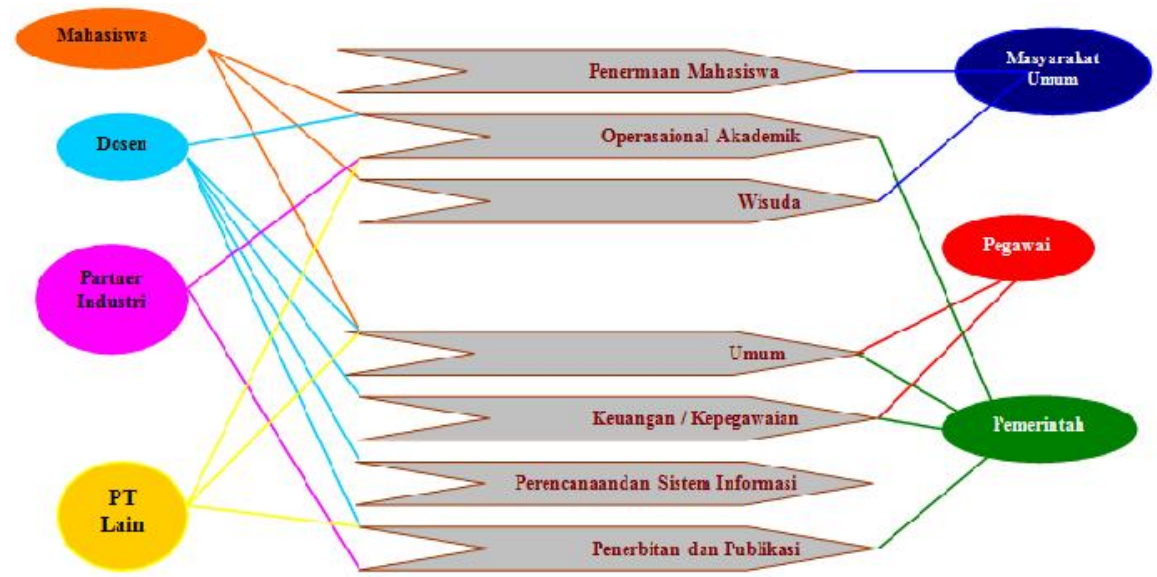

Gambar 2. Stakeholder utama perguruan tinggi

\subsection{Arsitektur sistem dan teknologi saat ini}

Sistem informasi dan teknologi saat ini memberikan gambaran tentang kondisi sistem dan teknologi informasi terkini, pengembangan teknologi informasi, keinginan dan arah pengembangan teknologi informasi di perguruan tinggi saat ini. Di dalam langkah ini beberapa hal yang perlu diperhatikan dan dijadikan sebagai kunci utama dalam melakukan analisa adalah :

a. Kondisi organisasi

b. Arah strategi pengembangan teknologi informasi 
c. Kondisi Sistem Informasi danTeknologi Saat Ini

\subsection{Pembangunan model arsitektur enterprise}

Dalam pembangunan model arsitektur, hal pertama yang dilakukan adalah pembuatan arsitektur data. Arsitektur data yang akan didefinisikan kali ini adalah definisi dari pemakaian data yang akan digunakan pada arsitektur aplikasi nantinya, yang akan disampaikan pada tahap ini sesuai dengan tahapan EAP dalam arsitektur data adalah:

a) Daftar kandidat entitas

Kandidat entitas merupakan entitas yang akan menjadi bagian dari perencanaan arsitektur enterprise, sehingga penentuannya dapat didasarkan pada kondisi fungsi bisnis utama pada rantai nilai yang telah terdefinisi sebelumnya, dengan demikian maka entitas yang akan didefinisikan adalah entitas bisnis dan berdasarkan entitas bisnis akan didefinisikan entitas data. Sesuai dengan kondisi rantai nilai tersebut, maka daftar entitas bisnis dan data ada di tabel 1 yang dapat diidentifikasi adalah sebagai berikut:

Tabel 1. Daftar entitas

\begin{tabular}{|c|c|}
\hline Entita Bisnis & Entitas Data \\
\hline \multirow{4}{*}{$\begin{array}{c}\text { Entitas Penerimaan } \\
\text { Mahasiswa }\end{array}$} & 1. Entitas Panitia PMB \\
\hline & 2. Entitas Soal Ujian PMB \\
\hline & 3. Entitas Peserta PMB \\
\hline & 4. Entitas Jenis Seleksi \\
\hline \multirow{16}{*}{$\begin{array}{c}\text { Entitas Operasional } \\
\text { Akademik }\end{array}$} & 5. Entitas Calon Mahasiswa \\
\hline & 6. Entitas Mahasiswa \\
\hline & 7. Entitas Dosen \\
\hline & 8. Entitas Mata Kuliah \\
\hline & 9. Entitas Registrasi \\
\hline & 10. Entitas Kelas \\
\hline & 11. Entitas Jurusan \\
\hline & 12. Entitas Ruang Kuliah \\
\hline & 13. Entitas Biaya \\
\hline & 14. Entitas Jadwal Kuliah \\
\hline & 15. Entitas Bukti Pembayaran \\
\hline & 16. Entitas Kurikulum \\
\hline & 17. Entitas Daftar Hadir Kuliah \\
\hline & 18. Entitas Daftar Hadir Dosen Mengajar \\
\hline & 19. Entitas Nilai \\
\hline & 20. Entitas Kalender Akademik \\
\hline \multirow{4}{*}{$\begin{array}{c}\text { Entitas Pelaksanaan } \\
\text { Wisuda }\end{array}$} & 21. Entitas Perwalian \\
\hline & 22. Entitas Alumni \\
\hline & 23. Entitas Stake Holder \\
\hline & 24. Entitas Sarana dan Prasarana \\
\hline \multirow{6}{*}{$\begin{array}{l}\text { Entitas Bagian } \\
\text { Umum }\end{array}$} & 25. Entitas Inventarisasi \\
\hline & 26. Entitas Pengadaan \\
\hline & 27. Entitas Monitoring Aset \\
\hline & 28. Entitas Anggaran \\
\hline & 29. Entitas Realisasi \\
\hline & 30. Entitas Pegawai \\
\hline Entitas Manajemen & 31. Entitas Perkiraan \\
\hline Keuangan dan & 32. Entitas Pendapatan \\
\hline \multirow[t]{4}{*}{ Kepegawaian } & 33. Entitas Pengeluaran \\
\hline & 34. Entitas Calon Pegawai \\
\hline & 35. Entitas Gaji \\
\hline & 36. Entitas Prestasi Pegawai \\
\hline \multirow{3}{*}{$\begin{array}{c}\text { Entitas Perencanaan } \\
\text { Sistem Informasi }\end{array}$} & 37. Entitas Laboratorium \\
\hline & 38. Entitas Software \\
\hline & 39. Entitas Sistem Informasi \\
\hline \multirow{3}{*}{$\begin{array}{l}\text { Entitas Penerbitan } \\
\text { dan Publikasi }\end{array}$} & 40. Entitas Jurnal \\
\hline & 41. Entitas Buletin \\
\hline & 42. Entitas Buku Ajar \\
\hline
\end{tabular}


Untuk menggambarkan hubungan antar entitas, maka penggambaran konseptual relasinya akan digunakan diagram Entity-Relationship (E-R). Diagram E-R Bidang Akademik merupakan model konseptual data logis yang menunjukkan hubungan antar entitas-entitas di bidang akademik di perguruan tinggi. Gambar 3 menunjukkan diagram E-R secara keseluruhan untuk aktivitas utama dan aktivitas pendukung pada bidang akademik.

Setelah mendefinisikan arsitektur data, kemudian akan dilanjutkan ke dalam pendefinisian arsitektur aplikasi. Arsitektur aplikasi yang akan diidentifikasikan adalah untuk membantu fungsi bisnis utama dari organisasi. Hal yang akan dilakukan untuk mendefinisikan aplikasi yang dibutuhkan oleh organisasi. Arsitektur aplikasi yang berhubungan dengan bidang pendidikan di dalam perguruan tinggi secara umum ditunjukkan pada tabel 2 .

Tabel 2. Arsitektur aplikasi

\begin{tabular}{|c|c|}
\hline Group Aplikasi & Sistem Aplikasi \\
\hline Sistem Ujian Seleksi Masuk & $\begin{array}{l}\text { Aplikasi Pendaftaran Calon Mahasiswa Baru } \\
\text { Aplikasi Pengelolaan Hasil Test } \\
\text { Aplikasi Registrasi Mahasiswa Baru }\end{array}$ \\
\hline Sistem Operasional Akademik & $\begin{array}{l}\text { Aplikasi Administrasi Kemahasiswaan } \\
\text { Aplikasi Pendaftaran Ulang } \\
\text { Aplikasi Administrasi Rencana Studi } \\
\text { Sistem Manajemen Kurikulum } \\
\text { Sistem Pembayaran Mahasiswa } \\
\text { Sistem Perwalian } \\
\text { Sistem Penjadwalan Kuliah } \\
\text { Aplikasi Pembuatan KRS dan KTM } \\
\text { Aplikasi Perubahan Rencana Studi } \\
\text { Sistem Administrasi Perkuliahan } \\
\text { Sistem Penjadwalan dan Administasi Ujian } \\
\text { Sistem Penilaian } \\
\text { Aplikasi Administrasi Seminar dan Ujian Komprehensif } \\
\text { Sistem Pelaporan Akademik }\end{array}$ \\
\hline $\begin{array}{c}\text { Sistem Administrasi Penglepasan } \\
\text { Akademik }\end{array}$ & $\begin{array}{l}\text { Sistem Pendaftaran Wisuda } \\
\text { Sistem Pengelolaan Alumni } \\
\text { Sistem Pembuatan Transkrip Nilai dan Ijazah }\end{array}$ \\
\hline Sistem Asses dan Inventarisasi & $\begin{array}{l}\text { Sistem Pandataan Asset } \\
\text { Sistem Peminjaman Asset } \\
\text { Sistem Perawatan dan Penghapusan Aset }\end{array}$ \\
\hline $\begin{array}{l}\text { Sistem Keuangan dan } \\
\text { Kepegawaian }\end{array}$ & $\begin{array}{l}\text { Sistem Rekrutmen } \\
\text { Sistem Pembelanjaan Pegawai } \\
\text { Sistem Administrasi Pegawai } \\
\text { Sistem Manajemen Pendidikan dan Pelatihan } \\
\text { Sistem Manajemen Cuti } \\
\text { Sistem Administrasi Perhitungan Honor dan Gaji } \\
\text { Sistem Anggaran } \\
\text { Sistem Akuntansi }\end{array}$ \\
\hline Sistem Administrasi Laboratorium & $\begin{array}{l}\text { Sistem inventarisasi laboratorium } \\
\text { Sistem penjadwalan pemakaian laporatorium }\end{array}$ \\
\hline Sistem Penerbitan dan Publikasi & $\begin{array}{l}\text { Sistem pendataan jurnal dan buletin } \\
\text { Sistem pencarian jurna dan buletin online }\end{array}$ \\
\hline
\end{tabular}

Tahap terakhir dalam memodelkan Arsitektur adalah mendefinisikan arsitektur teknologi. Dalam konsep EAP mendefinisikan kebutuhan teknologi perlu disediakan di lingkungan bisnis untuk menjalankan arsitektur data yang dapat mengelola data berdasarkan arsitektur aplikasi, dengan kata lain arsitektur teknologi merupakan kebutuhan infrastruktur yang harus disediakan untuk mendukung jalannya data dan aplikasi yang digunakan oleh organisasi.

Prinsip dan platform teknologi dibuat untuk mengidentifikasi jenis platform teknologi utama yang dibutuhkan untuk mendukung lingkungan shared data dan aplikasi di perguruan tinggi. Prinsip ini ditentukan dengan mempertimbangkan tren dan perkembangan teknologi informasi, model bisnis, arsitektur data, arsitektur aplikasi, sistem dan teknologi yang ada serta permintaan dan temuan dari pelaku bisnis di dalam organisasi. Di tabel 3 akan ditunjukkan platform teknologi yang dapat digunakan untuk mendukung data dan aplikasi di perguruan tinggi. 


\section{Tabel 3. Platform / arsitektur teknologi}

\begin{tabular}{|c|c|}
\hline Area Prinsip & Deskripsi \\
\hline \multirow[t]{3}{*}{ Sistem Operasi } & 1) Sistem operasi yang digunakan mendukung jaringan organisasi. \\
\hline & $\begin{array}{l}\text { 2) Sistem operasi yang dipilih bersifat portabel (dapat dijalankan pada beberapa } \\
\text { platform), skalabel (dapat dijalankan pada komputer berskala kecil hingga besar, } \\
\text { interoperable (dapat dijalankan pada lingkungan yang heterogen), kompatibel } \\
\text { (mempertahankan investasi perangkat lunak yangtelah ada dan memungkinkan } \\
\text { kemajuan teknologi diterapkan padakomponen yang telahada) }\end{array}$ \\
\hline & $\begin{array}{l}\text { 3) Sistem operasi mendukung sejumlah perangkat lunak dan aplikasi serta tool } \\
\text { pengembangan sistem }\end{array}$ \\
\hline \multirow[t]{3}{*}{ Perangkat Keras } & $\begin{array}{l}\text { 1) Perangkat keras harus andal dan memiliki tingkat ketersediaan yang tinggi serta } \\
\text { mendukung teknologi yang akan datang. }\end{array}$ \\
\hline & $\begin{array}{l}\text { 2) Pemilihan teknologi perangkat keras tidak berbasis fitur teknologi tertentu dan tidak } \\
\text { berfokus pada suatu merk. }\end{array}$ \\
\hline & 3) Perangkat keras enterprise harus memiliki tingkat layanan dan pemanfaatan yang tinggi \\
\hline \multirow[t]{6}{*}{$\begin{array}{l}\text { Komunikasi dan } \\
\text { Jaringan }\end{array}$} & $\begin{array}{l}\text { 1) Kapasitas jaringan menyediakan bandwidth untuk pengembangan masa depan dan } \\
\text { beragam format data. }\end{array}$ \\
\hline & $\begin{array}{l}\text { 2) Lingkungan jaringan disediakan dengan bandwidth yang memadai dan sekumpulan } \\
\text { protokol standar untuk mendukung layanan jaringan dan akses realtime terhadap } \\
\text { informasi. }\end{array}$ \\
\hline & $\begin{array}{l}\text { 3) Semua lokasi fisik dalam enterprise akan dihubungkan ke backbone jaringan. Laju dan } \\
\text { kapasitas interkoneksi ditentukan berdasarkan lokasi }\end{array}$ \\
\hline & $\begin{array}{l}\text { 4) Semua komponen yang dimanfaatkan dalam infrastruktur jaringan enterprise harus } \\
\text { memadai dan dapat di-upgrade serta diotorisasi dan pengelolaan dilakukan secara } \\
\text { terpusat. }\end{array}$ \\
\hline & $\begin{array}{l}\text { 5) Semua peralatan infrastruktur jaringan harus memiliki kemampuan untuk mendapatkan } \\
\text { dan merekam statistik kinerja jaringan. }\end{array}$ \\
\hline & $\begin{array}{l}\text { 6) Sistem jaringan komputer dan komunikasi data, dapat dimanfaatkan lebih lanjut untuk } \\
\text { melakukan komunikasi suara (voice) dengan transmisi gelombang suara melalui sarana } \\
\text { digital. }\end{array}$ \\
\hline \multirow[t]{4}{*}{ Aplikasi } & 1) Dokumentasi semиa aplikasi dibuat dan dikelola \\
\hline & $\begin{array}{l}\text { 2) Pengadaaan aplikasi diutamakan melalui pengembangan sendiri sebelum } \\
\text { mempertimbangkan untukmembeli. }\end{array}$ \\
\hline & 3) Seluruh rancangan aplikasi sebaiknya bersifat modular dan harus dapat diuji. \\
\hline & $\begin{array}{l}\text { 4) Melakukan manajemen konfigurasi terhadap aplikasi untuk menangani segala upaya } \\
\text { perubahan dan peningkatan melalui kendali versi }\end{array}$ \\
\hline \multirow{8}{*}{$\begin{array}{l}\text { Manajemen } \\
\text { Basis } \\
\text { Data }\end{array}$} & 1) Data dipisahkan dari aplikasi \\
\hline & 2) Data adalah sumber daya enterprise dan tidak dimiliki oleh suatu unit tertentu. \\
\hline & 3) Data ditangkap sekali dari sumbernya dan digunakan sesuai kebutuhan \\
\hline & 4) Akses data bebas dari hal lokasi dan struktur fisik dalam pandangan pemakai \\
\hline & $\begin{array}{l}\text { 5) Data di administrasikan secara terpusat dan dikelola untuk kemudahan akses serta } \\
\text { menganut konsep data warehouse. }\end{array}$ \\
\hline & $\begin{array}{l}\text { 6) Model basis data yang digunakan adalah basis data relasional yang relatif lebih mudah } \\
\text { dipahami dan lebih populer. }\end{array}$ \\
\hline & $\begin{array}{l}\text { 7) Informasi yang disimpan secara online tersedia secara terus menerus dan diperbaharui } \\
\text { secara berkala sesuai kebutuhan. }\end{array}$ \\
\hline & 8) Pemilihan DBMS disesuaikan dengan kebutuhan enterprise \\
\hline \multirow[t]{5}{*}{ Keamanan } & 1) Kebijakan dan standar keamanan meliputi akses fisik dan elektronis. \\
\hline & $\begin{array}{l}\text { 2) Akses ke sumber daya informasi enterprise akan diawasi secara terpusat oleh unit yang } \\
\text { berhubungan dengan teknologi informasi. }\end{array}$ \\
\hline & 3) Otorisasi aplikasi dan data dapat diberikan oleh unit terkait. \\
\hline & $\begin{array}{l}\text { 4) Kebutuhan keamanan meliputi secrecy (kebutuhan dalam sistem informasi yang hanya } \\
\text { boleh dibaca), availibility (kebutuhan bahwa sumber daya informasi hanya dapat } \\
\text { diperoleh dan dipakai olehpemakai yang berhak) dan integrity (kebutuhanbahwa } \\
\text { sumber daya informasi hanya dapatdimodifikasi dan dipelihara oleh unit terkait } \\
\text { yangberhak). }\end{array}$ \\
\hline & $\begin{array}{l}\text { 5) Infrastruktur server sudah didukung oleh kemampuan untuk menyandikan/meng-encrpty } \\
\text { data penting dan harus dapat perluas untuk server yang lain. }\end{array}$ \\
\hline
\end{tabular}




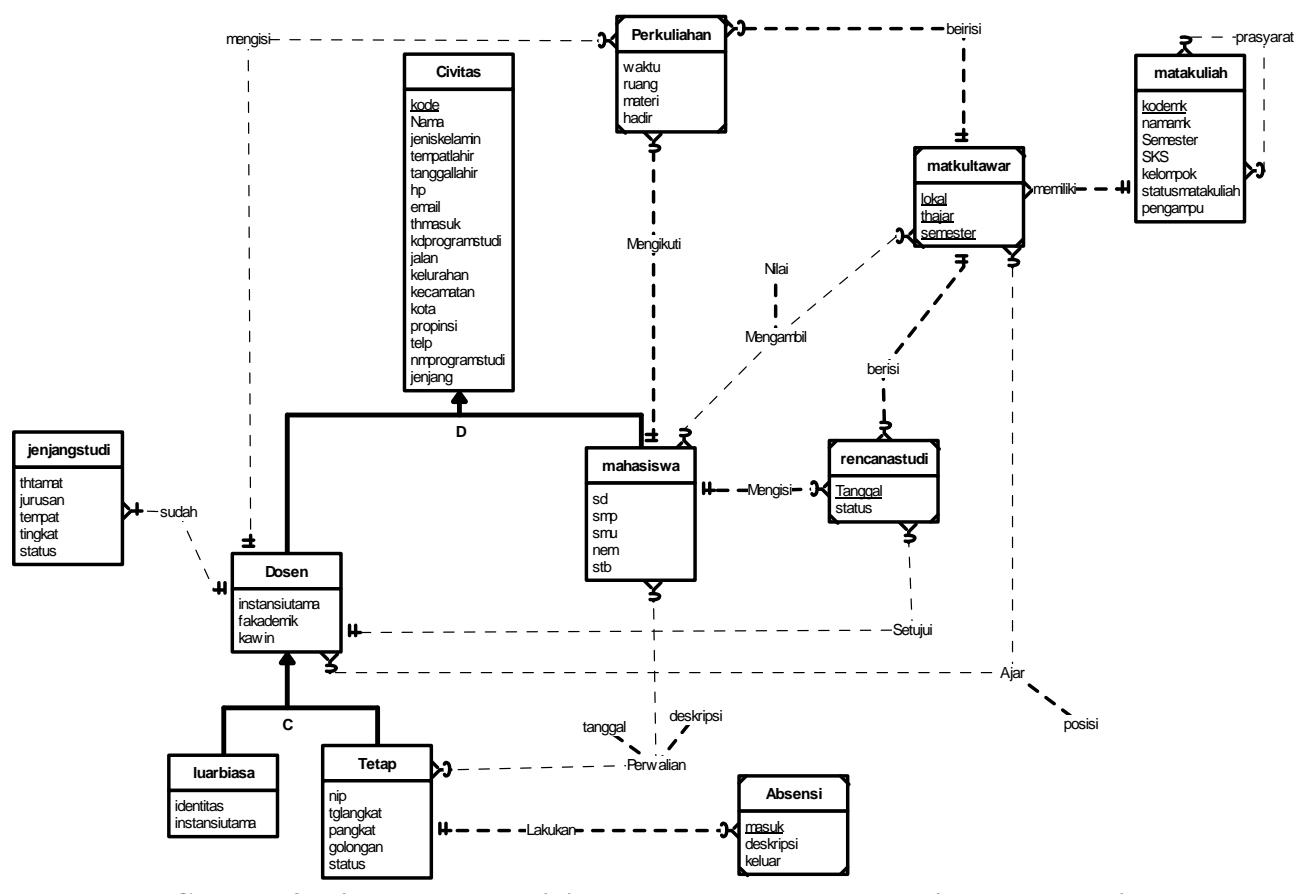

Gambar 3. Diagram E-R aktivitas utama dan pendukung bidang akademik

\section{KESIMPULAN}

EAP adalah salah satu framework yang berguna untuk membangun sebuah model atau blueprint yang berisikan arsitektur teknologi di dalam sebuah enterprise. Perguruan tinggi yang merupakan sebuah enterprise di bidang pendidikan bisa memanfaatkan EAP sebagai pedoman atau penuntun dalam membangun sebuah blueprint teknologi informasi untuk menunjang visi dan misinya.

Pemodelan arsitektur sistem informasi akademik di perguruan tinggi yang dibahas di jurnal ini menghasilkan sebuah contoh blueprint yang berisikan rantai nilai perguruan tinggi, hubungan antar stakeholder, daftar entitas, hubungan antar entitas yang ada, group dan sistem aplikasi dan platform teknologi.

\section{DAFTAR PUSTAKA}

[1] Lankhorst, Marc. (2009). Enterprise Architecture at Work., Berlin: Springer.

[2] Porter, Michael E. (1985). Competitive Advantage: Creating and Sustaining superior Performance, New York: The Free Press.

[3] Spewak Steven H. (1996). Enterprise Architecture Planning Developing a Blueprint for Data, Aplication, and Technology. New York: John Wiley \& Sons.

[4] Spewak Steven., and Tiemann Michael. 2006. "Updating The Enterprise Architecture Planning Model". Journal of Enterprise Architecture. 